\title{
The Psychic Distance Postulate Revised: From Market Selection to Speed of Market Penetration
}

PIA ARENIUS

HEC, University of Lausanne, BFSH-1, CH-1015 Lausanne, Switzerland

pia.arenius@unil.ch

\begin{abstract}
In this paper we revise the psychic distance postulate of the Uppsala Model (Johanson and Vahlne, 1977, 1990) by injecting more recent findings (i.e., distinguishing between selection of foreign markets and time needed to achieve sufficient penetration in foreign markets and the role of social capital). The model we propose posits that a higher psychic distance decreases the speed of market penetration. On distant markets, internationalizing technology-based ventures need more time to establish a position in the foreign network and to obtaining positive cash flow. Our model presents social capital as a mean to overcome the psychic distance and to increase the speed of market penetration. We build our model on four case studies on technology-based new ventures internationalizing at very early ages.
\end{abstract}

Keywords: Uppsala model, psychic distance, speed of market penetration

\section{Introduction}

The psychic distance postulate (Johanson and Vahlne, 1977, 1990) maintains that firms start their internationalization on close by markets at a minimal psychic distance, and gradually move to markets at successively greater distance. Psychic distance, the dominant concept of this study, is defined as factors, such as differences in language, cultures and business practices, that prevent and disturb the flow of information between the firm and the market. As the psychic distance increases, the more problematic information flows become. Only through experiential learning can firms overcome the psychic distance, and because learning takes time, the internationalization process of new firms tends to be gradual and incremental. New firms tend to start their internationalization on close by markets, and with increasing commitment and improved understanding of foreign markets, firms enter into markets that are increasingly dissimilar to their home market.

Technology-based new ventures appear to start their internationalization at "close" markets supporting the psychic distance postulate (e.g., Bell, 1995; Chetty and Blankenburg Holm, 2000; Coviello and Munro, 1997; Fontes and Coombs, 1997). However, these firms do not choose the market according to psychic distance (Bell, 1995; Madsen and Servais, 1997). In Bell (1995), the market selection of software firms was more influenced by domestic client followership, sectoral targeting, and industry trends, and than by the psychic distance of the market. Madsen and Servais (1997) proposed that the experience of the founders and partners, as well as the economic and 
capability or customer-related factors determine the location of foreign activities. Experience, like international working experience, experience in living abroad and other international experience, may shape the minds of the founders decreasing the perceived psychic distance (Madsen and Servais, 1997; McDougall et al., 1994), and also shape their networks and the social capital conveyed by these networks. Overall, the network approach seems to have merit in explaining the market selection of technology-based new ventures (Bell, 1995; Chetty and Blankenburg Holm, 2000; Coviello and Munro, 1997; Coviello and Munro, 1995). International opportunities are presented by network members (Chetty and Blankenburg Holm, 2000; Coviello and Munro, 1997; Coviello and Munro, 1995) and networks convey information and experiential learning can be replaced by network learning (Chetty and Blankenburg Holm, 2000).

The objective of this paper is to re-examine the psychic distance postulate of the Uppsala Model (Johanson and Vahlne, 1977, 1990) in light of recent findings on technologybased new ventures. In this paper we make a distinction between the selection of foreign markets, the time needed to achieve sufficient penetration in foreign markets (i.e., speed of market penetration in terms of Ayal and Zif (1979)) and the role of social capital. The model we develop in this paper proposes that the psychic distance affects the speed at which technology-based ventures penetrate the selected foreign markets. We define the speed of market penetration as the time needed from market entry until the generation of sales income from that market. On far-out markets, the psychic distance increases the liability of foreignness, which in turn increases the time needed to penetrate the foreign market area. Furthermore, the model proposes social capital as a mean to speed up the market penetration. We define social capital as the amount and quality of the external relationships possessed by the firm and the individuals involved in the firm. Social capital may help the firms to overcome their liability of foreignness on far-out markets, and thus enables them to penetrate these markets at an increased speed.

We will proceed to develop our arguments as follows. In the next section, we explain our research methodology and describe the four case companies we selected. In the main section, we will then build on the case studies and the literature on internationalization and social capital to develop our revised model of the psychic distance postulate. Finally, in the last section we will discuss the limitations of our theorizing and the boundary conditions of the proposed model, before we conclude by describing the theoretical and practical implications of the proposed model.

\section{Methods}

Because our interest was in model development, we chose the case method as our research strategy. Our choice of the case method was further motivated by our interest in highly complex processes that take a long time to unfold: this is a type of problem to which the case method is ideally suited (Yin, 1991). Our approach responds to the recent calls for case studies in internationalization theory. Jones (2001) called for studies focusing on more narrowly defined groups of firms generating rich data, and Chetty (1997) promoted the case study method showing how it allows researchers to 
study exporting as a dynamic process, not as something static. The strength of case study method lies in facilitating the study of the internationalization process from several perspectives, and facilitating a more thorough analysis of each firm than is possible in survey research. This enables us to become more knowledgeable about each firm, thus allowing new insights to emerge and enabling us to revise the psychic distance postulate.

We studied the early internationalization of four Finnish software firms. The evidence from multiple case studies is often considered more compelling and the results more robust (Yin, 1991: 52; Miles and Huberman, 1994: 29). By looking at a range of similar or contrasting cases, we can understand a single case finding, grounding it by specifying how and where, and if possible, why it carries as it does (Miles and Huberman, 1994: 29). Multiple cases reduce the risk of reporting chance associations (Eisenhardt, 1991). We also compared our results to other studies using software firm samples (Bell, 1995; Coviello and Munro, 1997; Coviello and Munro, 1995; Rasmussan, Madsen and Evangelista, 2001), to find support for our propositions.

A software firm sample is particularly suitable for our purpose of examining the effects of social capital. All our sample companies operate in emerging technology sector and therefore face the dual challenge of market creation and international expansion. They are involved in highly knowledge-intensive and interaction-intensive deliveries for customers situated in more or less dense value networks (Vallee, 2000), implying an interaction- and network-intensive mode of international entry (Johanson and Mattsson, 1988). The network approach has been given merit in previous studies on the internationalization of software firms (Bell, 1995; Coviello and Munro, 1995 1997; Rasmussan et al., 2001). In this paper, we will build on these studies and the social capital theory (e.g., Burt, 1992, 1997; Nahapiet and Ghoshal, 1998; Shane and Cable, 2002; Stuart, 1999; Stuart et al., 1999; Uzzi and Gillespie, 1999; Yli-Renko et al., 2001).

\section{Research setting}

The company selection criteria defines the setting of this study and builds a framework that states under which conditions the particular phenomenon is likely to be found as well as the conditions under which it is not likely to be found. We selected four case companies that all represented international new ventures; were under six years old; demonstrated a strategic intent for early and rapid internationalization; were independently held; addressed mainly business customers; and represented variance in terms of foreign market entry modes employed. To limit variation due to sector-specific influences, all case companies were selected from the software sector. This population has several characteristics that make it particularly suitable for the study of social capital and internationalization (e.g., knowledge intensity, existence of young internationally active firms). Finland is a knowledge-intensive and open market economy, and the act of going international does not represent a choice of whether or not to do it, but rather, when. Because the domestic market is relatively small, technology-intensive firms such 
as software product firms are forced to go international relatively early in their lives, and internationalization is an ongoing concern. Focus on a single industry of course limits the generalizability of our results, and thus our model should be regarded as a tentative and needing empirical validation.

In the following paragraphs, we introduce the case companies and describe their internationalization process. The case companies have been given fictive names to disguise their identity. These names are used throughout the empirical sections of the study. To further protect the company identity, precise figures are deliberately withheld, and some information remains secret.

Company A. Company A was established in 1997 to commercialize a benchmark software developed by another young Finnish software business. From inception, the firm has aimed at international markets, and in fact, it has never received any sales income from the domestic market. The company considers US its main - and only market area. At inception, it opened a sales subsidiary in UK, which was moved to Canada a year later and later on to US. Currently, the company has a sales subsidiary in the US. Company A has always had employees working at foreign locations, with a maximum of 15 people out of 45 .

Company B. Company B was established in 2000. The business idea was to create a completely new category of treasury-service tools. It sells high-end financial packages to large companies (single-purpose software with cross-business applications). It has been targeting international markets early on, and has mainly being following a push strategy targeting potential customers using a variety of lead-generation techniques. Company B has established two international sales offices in Europe (i.e., Sweden and UK). It has not been able to generate significant international sales income. In the beginning of 2002, the company employed 24 people, of whom two were working abroad.

Company C. Company $\mathrm{C}$ is the oldest of the four companies, being established in 1996 and employed around 45 people at the time of the study. It develops and markets software suites for IP-based wireless networks, operating systems, and equipment to be used by operators and users of future network generations. It has been seeking an international presence, but its efforts have been unsuccessful. In 2001, it opened a sales office in US to be closer to potential customers and partners. Company $\mathrm{C}$ is currently looking for partners both in Europe and in North America.

Company D. Company D was founded at the beginning of 1999. In less than 6 months, it had grown to employ 20 persons. It was clear from the beginning that company D's main markets were located outside of Finland. It established its first international subsidiary at the age of 17 months old and only four months later it appointed two new country managers in Europe. This case company was acquired in 2001 by another Finnish software company. At the time of the acquisition, there were more than 30 employees and almost $30 \%$ of the personnel was located outside Finland. At that time, it derived nearly $90 \%$ of its sales income from a single international market area. 


\section{Data collection}

In the first three cases (A, B, C), the data collection was carried out by the primary researcher. Most of the data collection on fourth case (D) was done by research associates. The advantage of having research associates who had not been involved in the initial framework development carrying out data collection is the avoidance of confirmatory bias. Additional interviews at company $\mathrm{D}$ were conducted by the primary researcher to supplement the existing material. We followed the internationalisation process of company A over a period of five years (1999-2003). The data collection for the other three firms was conducted during 2001-2002.

For each case 8 to 12 interviews were carried out, lasting between 60 and 150 minutes. Because a multiple-case study involves cross-case comparison, it requires some standardization of instrumentation so that the findings can be laid side by side in the course of analysis (Miles and Huberman, 1994: 35). The interviews were structured to some degree - some themes were discussed in every interview, but questions were open-ended and no priori categorization was used which may have limited the field of inquiry. As the interviews and the analysis of the material progressed, questions that were more specific were posed to the interviewees. Following good case research practice, all interviews were recorded and most were transcribed for content analysis. Triangulation and repeated visits to same informants were employed to ensure validity of the data collected.

Relying on a single source of information is not recommended in conducting case studies. Therefore, secondary source data, such as annual reports, newspaper clippings, www-pages, was collected in preparation, to challenge interviewees' memories if necessary, and to crosscheck their ex-post data. The secondary source data reflected the content of the interviews and was used as confirmatory source material. No independent analysis was carried out.

\section{Data analysis}

Keeping in mind that "our first obligation is to understand this one case" (Stake, 1995), the cases were first analyzed separately. For each of the four cases, a detailed description was first prepared. Most of the interviews were transcribed and the transcription and interview notes were arranged and systematized by themes by the primary researcher. Although theory-building case research should begin as close as possible to the idea of no theory under consideration and no hypotheses to test (Eisenhardt, 1989), existing literature can be used to specify possibly important constructs. Thus, in this study, some of the themes and constructs were derived from the extant literature; some of them arose from the case material.

Each individual case study consisted of a "whole" study, in which convergent evidence was sought about the facts and conclusions; the conclusions from each case were then considered as information needing replication in other individual cases. The data analysis proceeded from analyzing within-case data to searching for cross-case patterns 
(Eisenhardt, 1989). This allows the unique patterns of each case to emerge, which in turn are generalized across cases. Based on the individual case analysis, a preliminary model was formulated, which was then tested and developed further during the crosscase analysis.

As suggested by Eisenhardt (1989), three tactics were used to search for cross-case patterns. First, the dimensions suggested by the theory or current research problem were identified and within-group similarities and inter-group differences were identified. Second, pairs of cases were selected and similarities and differences listed. Third, data collected from different sources and of different types were compared. When a datasource pattern is corroborated by evidence from another source, the finding is better grounded (Eisenhardt, 1989: 541).

\section{The revised model of psychic distance}

In this section, we propose a model of psychic distance and speed of market penetration. As described in the introductory section, the proposed model examines the relationship between psychic distance and the speed of market penetration, and the moderating effect of social capital on this relationship.

\section{Re-examination of the market selection argument}

The main premise behind the Uppsala Internationalization model is that the process of internationalization is gradual and evolutionary (Johanson and Vahlne, 1977, 1990). Each firm goes through several logical steps of international behavior, based on gradual acquisition, integration, and the use of knowledge about foreign markets and operations, and on successively increasing commitments to foreign markets (Johanson and Vahlne, 1977). The Uppsala Internationalization model assumes that markets differ in terms of factors such as language, culture, business practices, education, industrial development and political systems. Johanson \& Wiedersheim-Paul (1975) called this difference the "psychic distance". Although exceptions commonly occur, the psychic distance is often correlated with the geographical distance in the foreign-market-selection process.

The model postulates that as the psychic distance between markets increases, the more difficult it becomes for firms to collect and interpret incoming information properly. Therefore, firms initially enter markets at a minimal psychic distance, and gradually move to those at successively greater distance. The speed at which it enters markets at greater distance is regulated by learning. More precisely, by experiential learning through the ongoing activities. Because of the tacit nature of market knowledge, the main source of learning is the firm's own operations. With increasing commitment and improved understanding of foreign markets, firms enter into markets that are increasingly dissimilar to their home market.

Numerous researchers have challenged the validity of the psychic distance postulate, finding that factors other than the psychic distance or the geographic closeness play 
an integral role in the selection of the initial market. Bell (1995), for example found little support for the psychic distance view in his study on small software firms in Finland, Ireland and Norway. Sectoral targeting and industry trends were stronger factors affecting market selection. According to Lindqvist (1997) study on small technologybased Swedish firms, market selection was more strongly influenced by large market potential and access to advanced customers. Czinkota and Ursic (1991) contended that the psychic distance was becoming much less relevant as global communication and transportation infrastructure improved and markets became increasingly homogeneous. Bell (1995) also found that software firms tend to enter those markets where their domestic customers operate. Networks and social capital have also been found importatn. Network partners provided the trigger for initial market selection in Coviello and Munro (1995), Coviello and Martin (1999) found that the market selection followed opportunities presented by various network members, and Johanson and Vahlne (2003) report on how existing relationships impact the market selection.

Our case evidence agrees with the studies challenging the original psychic distance postulate. Of the four case companies, only company D started its internationalization on close by Scandinavian markets (i.e., Sweden), but moved shortly thereafter to European markets (i.e., in the order of entry UK, Germany, Spain, Italy). Three of the four companies targeted more far-out countries from early on. Company A has focused solely on the US market. Company B targeted immediately European markets (UK, Sweden, Norway, in the order of entry). Also company C targeted the European market area (i.e., first Germany, then UK), but it rapidly continued its internationalization at far-out markets, opening its first ever international sales subsidiary in US. Even if one restricts the Uppsala model to predict the firm's choice of a new market early on, as suggested by Andersen (1993) and Luostarinen (1979), the psyhic distance appears not to predict market selection. Early on, without any experience, the case companies were approaching distant markets.

The case companies listed several factors influencing their market selection. Company A approached the US market because it considered the market as the biggest and most homogeneous, and also because its major technology partners were located there. Of the case companies, company A has been clearly most focused in its sales efforts: it only aimed at the US market. It did consider also other market areas, but "only after the North American market has been well taken care of". The firm is now years five old and has generated international sales income only from this market area.

For case company B, the primary influence on market selection was market potential, not easiness or low psychic or geographic distance. The company placed most emphasis on market opportunities, and appeared to know from early on which market had the best potential for their application. It found the US market unsuitable for several reasons, including that it was considered to be old fashioned in its application area, and that it had only limited market potential because most US companies do not have deal with the problem solved by company B's software. European countries, particularly UK and Germany, were considered the forerunners in this application area, and thus suitable for market penetration. For company D, the market selection was influenced by target-market characteristics and the reputational gain the firm would achieve if it 
succeeded: "if you can achieve market expansion on this market, and you develop your product there, you can address other international markets in a totally different way than if you succeed first in Finland."

The market selection factors listed by the companies are similar to those listed by Bell and Young (1998). In their view, the factors influencing foreign-market selection had changed since the mid-1970s when the Uppsala authors first proposed the principle. They posited that the relevance of the psychic distance in the internationalization process had diminished, and that other factors, such as those related to industry, the level of foreign-market demand and relationships with existing and prospective clients, exerted more influence on initial and consequent foreign-market selections.

Oviatt and McDougall (1997) suggested an alternative explanation asto why early international ventures appear not to follow the psychic distance postulate. According to Oviatt and McDougall (1997), early international ventures are endowed with internationally experienced managers, who need not to gain experiential learning of international markets. Instead, they can take advantage of their international experience and target distant markets immediately. This is confirmed by Crick and Jones (2000), who report that the market-selection decision was primarily based on the managers' experience in operating in international markets - in other words, on their previous employment - and the contacts they had developed. Some researchers also propose that international experience dissolves psychic distance, or at least changes founders' perceptions of distance to other countries (Madsen and Servais, 1997). Johanson and Vahlne (2003) discuss how learning and trust building can change perceived psychic distance. Dow (2000) report how the effect of psychic distance on market selection declined significantly between first and second market entry decision. Founders can compensate for the lack of personal experience by hiring internationally experienced personnel, who are able to overcome the psychic distance barrier (Coviello and Munro, 1999). The above studies suggest that the impact of psychic distance on managerial decision making decreases with international experience.

Our case evidence supported the experience related explanation. The managers of our case companies had strong international experience. A few of them had been studying abroad, whereas others had international work experience. All the managers were open to internationalization and expressed having an international vision early on. For the managers, internationalization was a logical step in the development of the company, and they did not appear to be hesitant or afraid of internationalization and targeting markets, which differed from the home market.

Case company A is particular interesting, as one of its founders was a foreigner. Having a foreign founder influenced significantly the early internationalization of this case company. Its first international sales subsidiary was not established on its target market (US), but it was established at this founder's home. Later on, as this founder moved to Canada, the office moved with him. Only after this founder left the case company, it opened a sales subsidiary in the US.

In their discussion on the exceptions of the Uppsala Model, Johanson and Vahlne (1990) do not account for individual-level experience and knowledge. They do discuss how firms can generalize their experience in one market to another if the markets are 
considerable similar. In fact, the Uppsala internationalization process model relies on firm routines and the firm's environment as the key factors for evolution. Individuals have been by far neglected by the theory. One could consider that Oviatt and McDougall (1997) are complementing or adding to the original Uppsala Model in highlighting the individuals as the level of analysis.

The current case evidence and the recent research finding suggest that the original psychic distance postulate is no longer valid. It appears that other factors outweigh the psychic distance in the foreign market selection decision. Such factors are suggested by the current case evidence and for example, by Bell (1995).

\section{Psychic distance, liability of foreignness and the speed of market penetration}

Internationalizing technology-based new firms suffer from liability of foreignness. In a sense, internationalizing ventures are new to foreign markets, because they have no active presence on the market and are missing a shared history and a shared social context. In the literature on multinational enterprises (Hymer, 1976), the liability of foreignness - the costs of doing business abroad that results in a competitive disadvantage for an MNE sub-unit - has been broadly defined as all additional costs a firm operating in a market overseas incurs and that a local firm would not incur. Zaheer (1995) lists four sources of liability of foreignness: (1) costs directly associated with spatial distance, such as the costs of travel, transportation, and co-ordination over distance and across time zones; (2) firm-specific costs based on a particular company's unfamiliarity with and lack of roots in a local environment; (3) costs resulting from the host country environment, such as the lack of legitimacy of foreign firms and economic nationalism; (4) costs from the home country environment, such as the restrictions on high-technology sales to certain countries imposed on U.S. - owned MNEs.

Our case companies felt that the biggest barriers for internationalization were caused by the lack of legitimacy and influence, and the need to learn new roles and establish relationships. They reported on their perception of foreign markets and market players, and perceived it to be easier for a fellow countryman/women to make business and sell products, as the following quotes illustrate: 'it seems easier for a fellow countryman to sell to a fellow countryman'. 'It's easier for a Swedish company to do business with a Swedish person, who is located in the nice city of Stockholm and speaks their native language'. 'There are cultural differences. You need to have an American to sell to an American company. A Finnish person just cannot do it. Maybe on the service sector, an earnest and serious Finn could work'. 'The German market is a bit complicated. They buy so willingly German products.'

Technology-based new ventures suffer from a greater liability of foreignness on distance markets. The more distant the market, the more difficult it is for the internationalizing firm to learn new roles and to fit into the foreign network. Thus, the higher the psychic distance, the higher is the liability of foreignness faced by the internationalizing venture on that market. In Grady and Lane (1996) the physic distance manifested itself among others as the difficulty to gain access to suppliers and the necessity to build 
long term relationships. The case companies experienced the psychic distance and the liability of foreignness in a very concrete manner. The case companies reported that the time they needed to establish the first contact with a potential customer was significantly longer in far out markets than on close-by areas. On close-by areas they were also able to use less personal contact methods than in far out markets. 'Out there... there is so much noise. One needs to figure out a way to get pass the noise and catch the attention. You need to know someone who knows someone who knows someone'.

The pace at which an international new venture penetrates a new market area is affected by speed at which it is able to locate customers and suitable partners, and close deals. Difficulties in establishing international partnerships has been one of the reported major factors slowing down internationalization (Karagozoglu and Lindell, 1998). Because of liability of foreignness, internationalizing ventures lack attractiveness in the eyes of potential customer and partners, because these lack information about the venture's competence and reliability. This may be particularly true in the software industry, which is characterized by abstract products and service, in which quality and other dimensions are difficult to articulate, and where output delivery is highly coupled with reputation. Because of lack of attractiveness, acquiring customers and closing deals takes time, and thus the market expansion is slowed down.

The case companies did report how the psychic distance affected the speed at which they were able to close business deals. The case companies were able to close business deals faster in close by markets (e.g., neighbouring countries). On close by markets, the case companies enjoyed credibility and trustworthiness. On distant markets, the case companies reported difficulties convincing customers of their capabilities and product quality. The customers were not prepared to deal with a new, unknown and untested venture or its products.

Furthermore, the value of their reference customers decreased the more distant markets they approached. The greater the distance between the target market and the origin of the reference customer, the lower was the value of the reference. On close by markets, the case companies could lessen the influence of liability of foreignness by proving themselves with the help of their domestic reference customers. At distant markets, the domestic references were useless.

Proposition 1. The psychic distance is negatively related to the speed of internationalization in terms of speed of market penetration on a foreign market area.

Social capital as moderator of the psychic distance and speed of market penetration relationship

We propose that social capital influences the proposed relationship between the psychic distance and the speed of market penetration. For the purpose of this study, we define social capital as the amount and quality of the external relationships possessed by the firm. On the network level, social capital consists of resources embedded in the network, such as reputation, credibility, and trustworthiness. In existing literature, the 
benefits of social capital accruing to internationalizing firms fall generally into two categories: information and control benefits (e.g., Burt, 1992, 1997; Nahapiet and Ghoshal, 1998) and resource benefits (e.g., Shane and Cable, 2002; Stuart, 1999; Stuart et al., 1999; Uzzi and Gillespie, 1999; Yli-Renko, Autio and Sapienza, 2001). For example, Knight and Cavusgil (2004) discuss how internationalising firms create strong relationships that provide market intelligence and cultivate new buyer segments. Gabrielsson and Gabrielsson (2003) propose that internationalising firms utilize horizontal product and marketing co-operation from the inception. Building on these previous studies on social capital and on our case evidence, we put forward a model, which posits that social capital moderates the relationship between the psychic distance and the speed of market expansion. Technology-based new ventures with social capital can expand at a higher speed on distant markets than those ventures without social capital. This is because social capital alleviates the liabilities of newness and foreignness faced by the internationalizing ventures, thus enabling these to overcome the psychic distance. Liabilities of newness and foreignness cause information, control, and resource problems, which social capital can partially solve. In the following, examples of these are presented from the literature and the case material.

First, internationalizing firms can use their social capital to access information and to interpret the incoming information. Information is not spread evenly across actors, and access to it may well be dependent on social contacts (Granovetter, 1985) and social relations may provide a vehicle for accessing and disseminating information (Nahapiet and Ghoshal, 1998). It is often less costly and more efficient than more formal mechanisms, for example tacit information is shared efficiently through networks (Nahapiet and Ghoshal, 1998; Tsai and Ghoshal, 1998). Social capital relates to both the amount of information potentially available to the firm and the amount of information actually disclosed to the firm. The higher the level of social capital in terms of the number of ties, the more there are network resources, including knowledge, potentially available to the firm. The higher the social capital in terms of the quality of the ties (the more trusting the ties are), the higher is the amount of knowledge actually disclosed to the firm.

We propose that internationalizing firms may use their social capital to access network foreign market knowledge (experiential knowledge of their partners), and substitute direct experiential learning by indirect experiential knowledge. According to the Uppsala model, experiential learning is the key factor regulating internationalization (Johanson and Vahlne, 1977). In the social capital view, experiential learning can be replaced by network learning. Firms endowed with social capital can gain access to the knowledge of other firms, without having to go through the same experiences as these firms. For the case companies, both the domestic and international networks of friends, previous colleagues, business acquaintances, and firms were used to obtain information. Social capital appeared to create information advantages to our case companies. They did receive information on international opportunities through their networks, in similar vein as reported by Lamont et al. (2000).

Second, in addition to facilitating learning and access to knowledge, social capital also helps the internationalizing firm to locate foreign partners. Technology-based 
new firms aiming to internationalize may obtain valuable contacts from their networks (Coviello and Munro, 1995). Our case companies did rely on their social capital to identify potential partners. Company A used the network contacts of the international founder to establish international R\&D partnerships, company B found its first international distributor with the help of its domestic customer. In contrast to Luostarinen (1994), the case companies entered into co-operative relationships early in their internationalisation.

Third, technology-based new ventures with social capital are also more attractive as partners and supplier than those ventures without social capital. The search for international partners is generally characterized by greater uncertainty and risk than the search for domestic partners. Decision makers, in practice, respond to the inherent risk associated with internationalization by placing more reliance on their social networks as a means to economize on these higher search costs (Eisenhardt and Schoonhoven, 1996). If the firm is unknown and its performance is uncertain, the status of the new firm and the quality of its outputs as perceived by others depend on the status of other firms with which it interacts. Eisenhardt and Schoonhoven (1996) pointed out that partnerships provide legitimacy and market power. In similar vein, Stuart, Hoang and Hybels (1999) proposed that relationships convey reputation. These researchers found that prominent relationships helped new ventures to acquire additional, well-known exchange partners, creating a cumulative cycle of advantage accruing to young firms that gain prominent organizational associates. In similar vein, Freeman (1999) showed that start-up businesses that received support from centrally-connected venture-capital companies were more likely to attract initial public offering subscriptions. Thus, social capital as networks and relationships enable technology-based ventures to overcome liabilities of newness and foreignness in international markets, and to speed up international market penetration.

Our case companies used their social capital to gain access to foreign partners and to negotiate cooperative agreements, and speeding up the partnering process. Having joint suppliers and customers, and industry associations, or being related through an employee's professional connections, is sometimes beneficial for partner identification and access. For example, Company A established several R\&D partnerships with equipment manufacturers with which the CMO had established connections in his previous work. In several instances did the case companies benefit from existing relationships in establishing new ones (e.g., company B with the Swedish software vendor, company A in establishing new R\&D and technology partnerships). In the case of company B, the negotiations went according to the CEO of company B "quite easily". Company $\mathrm{B}$ was able to penetrate rapidly the Scandinavian markets after building a partnership with a Swedish software vendor. Building this partnership was highly dependent on the social capital, which company B was able to build through its association with its founding organization.

Social capital did speed up the market penetration of the case companies also by facilitating access to foreign customers. One manager at company D explained that the key to rapid penetration into international markets was 'having the right country manager with existing networks in each market area. The country managers should have 
the customer contacts already there, so that we could tap into them and use them to our advantage.' In Europe, company B was able to use the professional contacts of the founders to gain access to customers and partners. Using these contacts, company B was able to start soon after founding negotiations in several market areas. Without these existing contacts, it would have taken the firm much longer to find the right customer contacts and to start sales negotiations.

The preceding discussion of case evidence and literature illustrates how technologybased new ventures can use their social capital to facilitate internationalization. The benefits of social capital are twofold. The information and control benefits include improved access to information and interpretation of incoming information. Second, social capital facilitates identification and access to local partners and customers. Consequently, social capital helps the internationalizing firms to overcome the liabilities of newness and foreignness, and thus contributes to an increased speed of foreign market penetration.

Proposition 2. On those distant markets, where the technology-based new ventures has a high level of international social capital, the speed of market penetration is higher than on those markets where it has a low level of international social capital.

\section{Discussion}

The purpose of the current paper is to revise the psychic distance postulate of the Uppsala internationalization model. The original psychic distance postulate posits that firms initially enter markets at a minimal psychic distance, and gradually move to those at successively greater distance (Johanson and Wiedersheim-Paul, 1975). Incremental learning at the level of the firm is the main factor explaining its internationalization. Firms are able to overcome the psychic distance by gaining direct experiential knowledge of foreign markets over time.

Based on case evidence, which was supported by recent research findings, we have proposed a revised psychic distance model. We found that the psychic distance has become less significant with respect to foreign market selection by technology-based new firms. However, we found that the psychic distance has a significant negative effect on the speed of market penetration. Speed of market penetration is defined in terms of the speed at which the technology-based new ventures establishes itself on the foreign market, e.g., identifies partner and customers, and eventually obtains sales income. According to the proposed model, the higher the psychic distance, the slower the speed of foreign market penetration. At distant markets, the technology-based new ventures suffer from liabilities of newness and foreignness, which hinder market penetration because these liabilities cause difficulties in the access to information, in the identification of partners and customer, and because they decrease the attractiveness of the technology-based new venture as a partner or supplier.

Furthermore, the proposed model posits that social capital moderates the negative relationship found between the psychic distance and the speed of market penetration. 
Technology-based new ventures with social capital can penetrate at a higher speed at distant markets than those ventures without social capital. This is because social capital alleviates the liabilities of newness and foreignness, thus enabling the internationalizing firm to overcome the psychic distance. Social capital is beneficial in terms of access to information, quality of information, identification of foreign partners and customers, and it also increases the attractiveness of the internationalizing firm in the eyes of the foreign firms.

Our methodology limits the generalizability of our results. Case studies are generalizable to theoretical propositions, not to populations or universes. In multiple-case studies, the researcher is generalizing from one case to the next on the basis of a match with the underlying theory, not with a larger universe. It is possible to generate mini-generalizations (Stake, 1995), which are generalizations within the cases or across the four cases. Generalization on statistical grounds is not possible. In this paper, we have revised the psychic distance postulate of the model based on four case studies on internationalizing software firms. This revised model needs to be verified in future quantitative studies, and the boundaries of the revised model need to be established.

The proposed negative relationship between psychic distance and the speed of market penetration has significant managerial implications. Managers need to be aware that markets differ with respect to the time needed to establish a position and to achieve positive cash flow. Managers need to view market selection as management of a portfolio: they need to balance the ratio of distant markets requiring a long time perspective and close by markets offering the possibility of obtaining quick positive income. Because internationalization is expensive and ventures are likely to need positive income early on, the ventures should approach close by markets to obtain early income, which then can be used to finance internationalization to more distant markets.

Technology-based new ventures have attracted significant venture capital investments and availability of capital has enabled these ventures to target distant markets and to disregard close by markets. The recent downturn in the venture capital industry may have an impact on the internationalization of technology-based new ventures, because obtaining funding has become increasingly difficult. The occurrence of so-called 'born global firms' or 'instant internationals' may be reduced by the economic developments. The economic development may also cause that the internationalizing ventures increasingly follow the traditional internationalization models. We might speculate that the international technology-based new ventures will increasingly target close by markets, because their financial resources have become more limited. The economic development certainly calls for further studies on the internationalization process of technology-based new firms.

Our proposed model makes a contribution to the internationalization theories. While it has been accepted that internationalization may not proceed in distinct and predetermined steps as predicted by the Uppsala Model, the basic logic behind the Uppsala model is arguably still a powerful model of the dynamism within the internationalizing firm (Melin, 1992). In this paper, we have examined one of its concepts, psychic distance, in detail. Our model assumes that this concept is still valid and our case evidence consolidates this assumption. We propose that the relevance of psychic distance 
in the internationalization process has not diminished, contradicting for example Bell and Young (1998). Nevertheless, we propose that the influence of psychic distance has changed, revising the original psychic distance postulate.

The Uppsala model relies on firm routines and the firm's environment as the key factors for evolution. Recent research on new international ventures has brought the importance of the individual entrepreneur and social capital to the forefront of internationalization (e.g., Bell, 1995; Chetty and Blankenburg Holm, 2000; Coviello and Munro, 1997; Coviello and Munro, 1995; Madsen and Servais, 1997; McDougall et al., 1994; Oviatt and McDougall, 1994). In this paper, we have revised the physic distance postulate, bringing in social capital into the internationalization process. Our proposed model relies on the original concepts of the Uppsala model, but proposes that the influences and outcomes of these concepts have changed. In this paper, we have focused on the psychic distance concept, the market entry decision and the speed of market penetration. We encourage further work on the other concepts and propositions of the Uppsala model.

\section{References}

Andersen, O. 1993, 'On the Internationalisation Process of Firms: A Critical Analysis', Journal of International Business Studies 24 (2), 209-231.

Ayal, I. and J. Zif, 1979, 'Market Expansion Strategies in Multinational Markets', Journal of Marketing 43, 84-94.

Bell, J. 1995, 'The Internationalization of Small Software Firms-A Further Challenge to the 'Stage' Theories', European Journal of Marketing 29 (8), 60-75.

Bell, J. and S. Young, 1998, 'Towards an Integrative Framework of the Internationalization of the Firm', in G. Hooley, R. Loveridge, and D. Wilson (eds.), Internationalisation: Process, Context and Markets. MacMillan: London.

Burt, R.S. 1992, Structural holes: The Social Structure of Competition. Harvard University Press: Cambridge. Burt, R.S. 1997, 'The Contingent Value of Social Capital,' Administrative Science Quarterly 42, 339-365.

Chetty, S. 1997, 'The Case Study Method for Research in Small- and Medium-sized Firms,' International Small Business Journal 15(1), 73-85.

Chetty, S. and D. Blankenburg Holm, 2000, 'Internationalisation of Small to Medium-Sized Manufacturing Firms: A Network Approach', International Business Review 9, 77-93.

Coviello, N.E. and K.A.-M. Martin, 1999, 'Internationalization of Service SMEs: An Integrated Perspective From the Engineering Consulting Sector', Journal of International Marketing 7 (4), 42-66.

Coviello, N.E. and H.J. Munro, 1997, 'Network Relationships and the Internationalization Process of Small Software Firms', International Business Review 6 (4), 361-386.

Coviello, N.E. and H.J. Munro, 1995, 'Growing the Entrepreneurial Firms: Networking for International Market Development', European Journal of Marketing 29 (7), 49-61.

Crick, D. and M.V. Jones, 2000, 'Small High Technology Firms and International High Technology Markets', Journal of International Marketing 8 (2), 63-85.

Czinkota, M.R. and M. Ursic M. 1991, 'Classification of Exporting Firms According to Sales and Growth into a Share Matrix', Journal of Business Research 22 (3), 243-253.

Dow, D. 2000, 'A Note on Psychological Distance and Export Market Selection', Journal of International Marketing 8 (1), 51-64.

Eisenhardt, K.M. 1989, 'Building Theories from Case-Study Research', Academy of Management Review 14 (4), 532-550. 
Eisenhardt, K.M. 1991, 'Better Stories and Better Constructs- the Case For Rigor and Comparative Logic', Academy of Management Review 16 (3), 620-627.

Eisenhardt, K.M. and C.B. Schoonhoven, 1996, 'Resource-Based View of Strategic Alliance Formation: Strategic and Social Effect in Entrepreneurial Firms', Organization Science 7 (2), 139-150.

Fontes, M. and R. Coombs, 1997, 'The Coincidence of Technology and Market Objectives in the Internationalization of New Technology-Based Firms', International Small Business Journal 15 (4), 14 35.

Freeman, J. 1999, 'Venture Capital as an Economy of Time', in RTAJ Leenders and SM Gabbay (eds.), Corporate Social Capital and Liability: Kluwer Academic Publisher: Norwell, MA, pp. 460-479.

Gabrielsson, M. and Gabrielsson, P. 2003, 'Global Marketing Strategies of Born Globals and Globalising Internationals in the ICT Field', Journal of Euromarketing 12 (3/4), 123-145.

Grady, S. and W.H. Lane, 1996, 'The Psychic Distance Paradox', Journal of International Business Studies(Second Quarter), 309-333.

Granovetter, M., 1985, 'Economic Actions and Social Structure: The Problem of Embeddedness', American Journal of Sociology 91 (3), 481-510.

Hymer, S. 'The International Operations of National Firms: A Study of Direct Investments', MIT Press, (1976).

Johanson, J. and L.G. Mattsson, 1988, 'Internationalization in Industrial Systems—a Network Approach', in N Hood and JE Vahlne (eds.), Strategies in Global Competition. Croom Helm: London.

Johanson J. and J.E. Vahlne, 1977, 'The Internationalization Process of the Firm-A model of Knowledge Development and Increasing Foreign Market Commitments', Journal of International Business Studies 8 (1), 23-32.

Johanson, J. and J.E. Vahlne, 1990, ‘The Mechanism of Internationalisation', International Marketing Review $7(4), 11-25$

Johanson, J. and J.E. Vahlne J-E, 2003, 'Business relationship learning and commitment', Journal of International Entrepreneurship 1, 83-101.

Johanson, J, and F. Wiedersheim-Paul, 1975, 'The Internationalization of the Firm-Four Swedish Cases', Journal of Management Studies 12 (3), 305-322.

Jones, M.V. 2001, 'First Steps in Internationalisation: Concepts and Evidence from a Sample of Small High-Technology Firms', Journal of International Marketing 7, 191-210.

Karagozoglu, N and M. Lindell, 1998, 'Internationalization of Small and Medium-Sized Technology-Based Firms: An Exploratory Study', Journal of Small Business Management, 44-59.

Knight, G. and S.T. Cavusgil, 2004, 'Innovation, Organizational Capabilities, and the Born-Global Firm', Journal of International Business Studies 35, 124-141.

Lamont, B.T., V. Sambamurthy, K.M. Ellis, and P.G. Simmonds, 2000, 'The Influence of Organizational Structure on the Information Received by Corporate Strategists of Multinational Enterprises', Management International Review 40 (3), 231-252.

Lindqvist, M. 1997, 'Infant Multinationals: Internationalisation of Small Technology-Based Firms', in D Jones-Evans and M Klofsten (eds.), Technology, Innovation and Enterprise, The European Experience. MacMillan Press Ltd.: Hampshire.

Luostarinen, R. Internationalisation of the firm. Doctoral thesis, A: 30, Helsinki School of Economics: Finland.

Luostarinen, R. 1994, Internationalisation of Finnish firms and their response to global challenges. UNU World Institute for Development Economic Research: Finland.

Madsen, T.K. and P.Servais, 1997, 'The Internationalization of Born Globals: An Evolutionary Perspective', International Business Review 6 (6), 561-583.

McDougall, P.P., S. Shane, and B.M. Oviatt, 1994, 'Explaining the Formation of International New Ventures-the Limits of Theories from International-Business Research', Journal of Business Venturing 9 (6), 469-487.

Melin, L. 1992, 'Internationalization as a Strategy Process', Strategic Management Journal 13, 99-118.

Miles, M.B. and A.M. Huberman, 1994, Qualitative Data Analysis: An expanded sourcebook. Sage: Thousand Oaks, CA. 
Nahapiet, J. and S. Ghoshal, 1998, 'Social Capital, Intellectual Capital, and the Organizational Advantage', Academy of Management Review 22 (2), 242-266.

Oviatt, B.M. and P.P. McDougall, 1994, 'Toward a Theory of International New Ventures', Journal of International Business Studies 25 (1), 45-64.

Oviatt, B.M. and P.P. McDougall, 1997, 'Challenges for Internationalization Process Theory: The Case of International New Ventures', Management International Review special issue 1997/2, 85-99.

Rasmussan, E.S., T.K. Madsen, and F. Evangelista, 2001, 'The Founding of the Born Global Company in Denmark and Australia: Sensemaking and Networking', Asia Pacific Journal of Marketing and Logistics 75-107.

Shane, S. and D. Cable, 2002, 'Network Ties, Reputation, and the Financing of New Ventures', Management Science 48 (3), 364-381.

Stake, R.E. 1995, The Art of Case Study Research. Sage: Thousand Oaks.

Stuart, T.E., 1999, 'Technological Prestige and the Accumulation of Alliance Capital', in RTAJ Leenders and SM Gabbay (eds.), Corporate Social Capital and Liability, Kluwer Academic Publisher: Norwell, MA, pp. 376-389.

Stuart, T.E., H. Hoang, and R.C. Hybels, 1999, 'Interorganizational Endorsements and the Performance of Entrepreneurial Ventures', Administrative Science Quarterly 44, 315-349.

Tsai, W. and S. Ghoshal, 1998, 'Social Capital and Value Creation: The Role of Intrafirm Networks', Academy of Management Journal 41 (4), 464-476.

Uzzi, B. and J.J. Gillespie, 1999, 'Corporate Social Capital and the Cost of Financial Capital: An Embeddedness Approach', in RTAJ Leenders and SM Gabbay (eds.), Corporate Social Capital and Liability, Kluwer Academic Publisher: Norwell, MA, pp. 446-459.

Vallee, A., 2000, 'Reconfiguring the Value Network', Journal of Business Venturing 21, 4.

Yli-Renko, H., E. Autio, and H. Sapienza, 2001, 'Social Capital, Knowledge Acquisition, and Knowledge Exploitation in Young Technology-Based Firms', Strategic Management Journal 22, 587-613. 